\title{
ANALISIS DAMPAK COVID 19 PADA UMKM PROVINSI GORONTALO
}

\author{
Juniaty Ismail \\ Instutut Agama Islam Negeri Sultan Amai Gorontalo \\ juniatyismail@iaingorontalo.ac.id
}

\begin{abstract}
Abstrak: Analisis Dampak Covid 19 Pada UMKM Provinsi Gorontalo. Penelitian ini memiliki tujuan untuk mengetahui sejauh mana dampak covid 19 pada Usaha Mikro Kecil Menengah yang ada di wilayah Provinsi Gorontalo. Sejak diberlakukannya kebijakan Pembatasan Sosial Berskala Besar oleh Pemerintah Indonesia dan Pemerintah Provinsi Gorontalo khususnya, banyak pelaku-pelaku usaha mengalami kesulitan dalam krisis pandemic ini. Dengan menggunakan metode penelitian statistik deskriptif, hasil temuan menyatakan bahwa pandemic covid 19 ini sangat berdampak signifikan terhadap pertumbuhan ekonomi UMKM di Provinsi Gorontalo terutama pada aspek hutang usaha yang meningkat selama masa pandemic, aspek perolehan omzet yang berdampak pada penurunan laba usaha serta dari aspek jangkauan pemasaran yang juga ikut menurun.
\end{abstract}

Kata Kunci: Hutang Usaha; Penurunan Laba; Jangkauan Pemasaran; Covid 19; UMKM

Abstract: Analysis of The Impact of Covid 19 On MSMES In Gorontalo Province. This study aims to determine the extent of the impact of Covid 19 on Micro, Small and Medium Enterprises in Gorontalo Province. Since the implementation of the Large-Scale Social Restrictions policy by the Government of Indonesia and the Provincial Government of Gorontalo in particular, many business actors have experienced difficulties in this pandemic crisis. By using the descriptive statistical research method, the findings state that the Covid 19 pandemic has a very significant impact on the economic growth of MSMEs in Gorontalo Province, especially in the aspect of business debt which increased during the pandemic, the aspect of turnover which has an impact on decreasing operating profits as well as from the aspect of marketing outreach. which also declined.

Keywords: Business Debt; Reducing Profits; Marketing Range; Covid 19; MSMEs

\section{PENDAHULUAN}

Pandemi COVID-19 mengubah dunia seperti yang sudah kita ketahui. Di Eropa, khususnya di Kanada misalnya, tingkat pengangguran melonjak signifikan sebesar 13,7\% pada bulan Mei Tahun 2020, padahal sebelumnya di bulan yang sama di tahun 2019 hanya sebesar $5.4 \%$. Hal ini mengakibatkan Indeks konsumsi menurun 47,6 \% (Renner, 2020). Lebih dari separuh pemilik UMKM di Kanada yang memiliki kurang dari 20 karyawan melaporkan adanya penurunan pendapatan atau omzet sebesar 20\% atau lebih (Lim et al., 2020). Pemerintah Kanada, menawarkan subsidi upah yang mencakup hingga $75 \%$ dari gaji karyawan, pemerintah juga mendorong pihak kreditur memberikan pinjaman darurat tanpa bunga hingga $\$ 40.000$ untuk para pebisnis kecil UMKM yang memenuhi syarat, selain itu pemerintah Kanada juga memberi penangguhan pembayaran pajak sebagai langkah lain untuk membantu 
menutupi biaya operasional UMKM. Langkah-langkah atau upaya pemerintah ini berfokus pada pencegahan kebangkrutan UMKM dan perlindungan kelangsungan hidup para pekerja (Lim et al., 2020). Peranan penting yang dimainkan oleh UMKM, berorientasi pada pertumbuhan ekonomi, pengembangan inovasi, serta penciptaan lapangan kerja, di seluruh lapisan masyarakat (Cowling M, Liu W \& Ledger A, 2015 ; Senderovitz M, 2016).

Pandemi covid 19 berpotensi memiliki dampak positif dan negatif pada pertumbuhan usaha, mikro, kecil dan menengah (UMKM). Sebab perusahaan sebagai sistem dari berbagai komponen sumber daya, baik strategis, fisik, keuangan, manusia dan sumber daya organisasi lainnya, serta perusahaan sebagai pertumbuhan dan perluasan dari sistem sumber daya ini. Berdasarkan data kualitatif yang diambil dari UMKM di Kanada yang pertumbuhannya tinggi, potensi dampak dari krisis pandemi terjadi pada komponen sistem sumber daya. Sumber daya ini berkembang bersama, melalui berbagai umpan balik. Kemunduran pertumbuhan sementara yang dialami oleh UMKM, sebenarnya dapat memberikan peluang pada pengusaha untuk menyelaraskan kembali, dan mendapatkan kembali keseimbangan yang cocok dengan sistem sumber daya perusahaan mereka. Penataan kembali ini memungkinkan perusahaan untuk berkembang lebih baik lagi pada fase berikutnya (Lim et al., 2020).

Di Asia Barat, khususnya di Republik Armenia, analisis dampak pandemi Covid 19 pada usaha mikro, kecil dan menengah menunjukkan bahwa dibandingkan dengan karyawan di perusahaan-perusahaan besar, karyawan UMKM lebih terkena dampak krisis diberhentikan atau dikurangi jam kerja dan gajinya. Namun, di sektor lain, terdapat juga dukungan pada karyawan yang memungkinkan untuk bekerja dari jarak jauh, misalnya pada sektor pendidikan, layanan informasi dan komunikasi, serta mereka yang memiliki kualifikasi profesional tingkat menengah hingga tingkat atas, yang tidak terlalu terpengaruh oleh dampak krisis pandemi Covid 19. Untuk itu dibutuhkan bantuan pemerintah yang lebih tepat sasaran pada UMKM yang memiliki pekerja berketerampilan rendah (Beglaryan \& Shakhmuradyan, 2020).

Kasus pertama infeksi virus corona di Republik Armenia didaftarkan pada 1 Maret 2020. Untuk menahan penularannya, Pemerintah Republik Armenia memberlakukan keadaan darurat pada pertengahan Maret, yang mengharuskan penutupan semua usaha kecuali toko kelontong, apotek, dan bank, yang kemudian pemberlakuan pembatasan tersebut dicabut pada awal hingga pertengahan Mei, delapan 
belas program Pemerintah yang bertujuan untuk mengurangi dampak krisis pandemi khususnya pada lini ekonomi dan sosial menyerap anggaran sebesar 84,4 miliar atau 4,8\% dari PDB. Para akademisi baik di luar negeri maupun di Republik Armenia telah menilai biaya yang dikeluarkan pada lini ekonomi dan sosial untuk menekan krisis pandemi tersebut mempengaruhi ekonomi nasional dan ekonomi global (Atkeson, 2020; Avanesyan, 2020; Baldwin, R., \& Weder di Mauro, 2020; Fernandes, 2020; Gourinchas, 2020; McKibbin, W. J., \& Fernando, 2020). Analisis ini menggarisbawahi bahwa dalam skala dan cakupannya, krisis pandemi ini melampaui krisis keuangan 2008-2009 dan sebanding dengan krisis hebat pada tahun 1929-1933 di Amerika Serikat dan kehancuran pada masa perang tahun 1939-1945 di Eropa. Tidak mengherankan, para pemimpin berbagai Negara telah mensejajarkan antara memerangi pandemi dan memobilisasi dana untuk perang, meningkatkan pengeluaran kas Negara untuk kepentingan publik secara sepadan.

Di Indonesia, Covid 19 memasuki babak baru sejak pertama kali menyebar pada kasus pertama yang diumumkan pada awal Maret 2020. Penyusutan Omzet Pebisnis UMKM akibat covid 19 sangat signifikan sejak awal kemunculannya. Salah satu Industri yang paling terdampak pada penyebaran virus ini ialah Industri Pariwisata. Menurunnya sektor pariwisata mempunyai domino effect terhadap bisnis UMKM. Bersumber pada informasi yang diolah P2E LIPI, akibat penyusutan pariwisata terhadap UMKM yang bergerak dalam usaha mikro makanan serta minuman menyentuh angka $27 \%$. Sementara dampak terhadap bisnis kecil makanan serta minuman sebesar 1, 77\%, serta usaha menengah pada angka 0,07\%. Dampak covid 19 pada bisnis jenis kerajinan dari kayu serta rotan (hadycraft), usaha mikro berada pada posisi angka 17,03\%. Usaha kecil pada kerajinan kayu serta rotan pada angka $1,77 \%$ serta usaha menengah pada angka 0, 01\%. Di sisi lainnya, tingkat konsumsi pada rumah tangga pula terkoreksi antara $0,5 \%$ sampai $0,8 \%$ (Amri, 2020).

Perkembangan dan kemajuan era digital dalam globalisasi sangat mempengaruhi roda ekonomi termasuk pada pasar ritel. Karena covid 19, pasar-pasar ritel yang modern, baik skala besar, mikro, sampai kecil mulai menghadapi penurunan omzet. Walaupun dengan memperkenalkan kemudahan dan fleksibilitas berbelanja pada realitasnya di masa digital saat ini, orangorang tetap saja enggan serta lebih suka melaksanakan kegiatan belanja online ataupun memakai aplikasi media. Banyak keuntungan yang ditawarkan pada metode belanja online. Sebagian langkah agar bisa 


\section{Nominal: Barometer Riset Akuntansi dan Manajemen \\ P-ISSN: 2303-2065 E-ISSN: 2502-5430 \\ Volume 10 No 2 (2021)}

mempertahankan eksistensinya di pasar pada masa digital sekarang ini, refokus pada pelanggan serta industri rethinking, merancang strategi sosial serta digital serta mengembangkan kemampuan organisasi (Amri, 2020).

Beberapa strategi dapat dikerahkan para pelaku bisnis UMKM dalam menjaga kestabilan dan keberlangsungan usahanya menghadapi krisis covid 19. Pebisnis UMKM dapat menyesuaikan diri dengan mengaplikasikan konsep OODA loop berupa konsep analisis berulang dari observe, orient, decide dan act, untuk menentukan keputusan dari suatu masalah, sehingga ancaman krisis pandemi covid 19 yang menimpa UMKM bisa segera ditindaki dengan cepat dan tepat (Richards, 2008). Setelah menerapkan konsep OODA loop, bagian dari langkah analisis tersebut adalah dengan mengamankan asset dalam hal ini mempertahankan posisi kestabilan dana tunai yang dikenal dengan istilah cash is king. Langkah selanjutnya yaitu menciptakan jejaring baru pada relationship marketing, mempertahankan customer lama dan merekrut customer baru. Hal paling penting berikutnya adalah meningkatkan skill atau kemampuan pengusaha dan karyawan dalam memanfaatkan perkembangan teknologi informasi. Dari semua strategi-strategi yang dapat dilakukan tersebut, akan memiliki keseimbangan nantinya jika menyelipkan sisi spritualitas di dalamnya, meningkatkan hubungan dengan Pencipta, manusia, serta alam lingkungan sekitar (Ismail, 2020).

Dampak pandemi covid 19 ini tentunya juga berimbas pada UMKM yang ada di Provinsi Gorontalo, sebuah Provinsi di daratan Sulawesi Utara yang menjadi Provinsi terakhir dalam melaporkan kasus pertama infeksi covid 19 di tahun 2020. Jumlah UMKM di Provinsi Gorontalo ini meningkat dari tahun ke tahun. Tentu krisis pandemi covid 19 ini juga memporakporandakan eksistensi UMKM di Provinsi Gorontalo. Bagaimana dampak covid 19 pada UMKM di Provinsi Gorontalo?, berdasarkan fenomena yang ada dengan tujuan meninjau dampak covid 19 pada hutang usaha, laba usaha, dan pemasaran produk UMKM di Provinsi Gorontalo. Sehingga diharapkan nanti hasil penelitian ini dapat memberikan informasi baru terhadap kebijakan-kebijakan Pemerintah Provinsi ke depannya terlebih pada peningkatan dan perlindungan pertumbuhan UMKM di Provinsi Gorontalo.

\section{KAJIAN LITERATUR}

Menurut SFAC No. 6, hutang atau kewajiban adalah "pengorbanan manfaat ekonomi masa depan untuk menyerahkan sejumlah aktiva atau jasa kepada entitas lain di masa depan yang timbul karena keharusan 


\section{Nominal: Barometer Riset Akuntansi dan Manajemen \\ P-ISSN: 2303-2065 E-ISSN: 2502-5430 \\ Volume 10 No 2 (2021)}

masa sekarang." Ikatan Akuntan Indonesia menyatakan hutang perusahaan masa kini akibat peristiwa masa lampau, dan penyelesaiannya mengakibatkan arus kas keluar di masa depan. Karakteristik kewajiban diantaranya:

1. Pengorbanan untuk manfaat ekonomi di masa depan

a. Bersifat memaksa

b. Ada pihak lain yang terlibat

c. Terdapat tugas dan tanggung jawab untuk mentransfer dari sumber ekonomi pada pihak lainnya

d. Jumlahnya bisa ditentukan dengan cara yang layak.

2. Keharusan sekarang

a. Kejelasan ada pada tanggal saat pelaporan

b. Dapat dilunasi sekarang (sesuai tanggal neraca), walaupun belum saatnya dilunasi

c. Aspek yuridis bukanlah satu-satunya faktor yang menentukan saat muncul kewajiban yang sekarang.

3. Transaksi dimasa lalu

Transaksi dan kejadian pada masa yang lalu adalah kriteria dalam mengakui kewajiban.

Chaniago (1998) berpendapat bahwa omzet penjualan merupakan total jumlah pendapatan yang diperoleh dari hasil penjualan atau perdagangan suatu barang dan jasa pada kurun waktu tertentu. Swastha
(1993) mengemukakan omzet penjualan merupakan total keseluruhan dari aktivitas penjualan suatu produk atau barang dan jasa yang kemudian dihitung keseluruhannya pada kurun waktu tertentu dengan cara terus menerus pada saat proses akuntansi. Dari pengertian tersebut disimpulkan makna omzet penjualan merupakan totalitas jumlah barang dan jasa yang dijual pada kurun waktu tertentu, yang kemudian dihitung atas dasar perolehan jumlah uang (Rosita, 2020).

Laba adalah informasi kondisi keuangan yang terkait dengan kegiatan operasional perusahaan. Sebab laba berasal dari komponen yang berkaitan dengan kegiatan operasional perusahaan yakni pendapatan dan juga beban (Apriliana, 2012). Menurut PSAK No. 25 kemampuan perusahaan dalam menghasilkan arus kas pada masa depan bisa diperkirakan dengan dasar informasi yang bersumber dari laporan laba rugi (Janita, 2012). Laba juga dapat memprediksikan arus kas pada masa depan jika dibagi ke berbagai komponen akrual dalam hal ini laba kotor, laba operasional serta laba bersih. Hal ini dikarenakan perhitungan yang menggunakan laba kotor hanya dapat berisikan sejumlah komponen pengeluaran atau biaya serta pendapatan jika dibandingkan dengan jumlah laba bersih dan laba operasional (Janita, 2012).

Pemasaran menurut pendapat Philip Kotler (2004) merupakan proses 
pengelolaan sosial, disaat individu-individu atau kelompok-kelompok mendapatkan apa yang menjadi kebutuhan serta keinginan mereka, melalui penciptaan serta tukar menukar produk yang bernilai dengan pihak lainnya. Pemasaran ini memiliki tujuan untuk memenuhi keinginan serta kebutuhan konsumen hingga produk dan jasa dapat sesuai dengan selera konsumen serta produk atau jasa ini dapat terjual. Pelaku pemasaran dituntut agar dapat mengerti permasalahan utama di bidangnya dan bisa memberi gambaran jelas serta terarah mengenai apa saja yang sudah dilakukan oleh perusahaan serta dapat menyusun strategi sehingga tujuan perusahaan tercapai (Danang Sunyoto, 2012).

Pemasaran berperan penting dalam mencapai keberhasilan suatu usaha, karenanya bidang pemasaran punya peranan dalam mewujudkan perencanaan suatu usaha. Hal ini bisa wujudkan apabila perusahaan ingin bertahan dan meningkatkan penjualan pada barang atau jasa yang diproduksi. Melalui penerapan strategi pemasaran yang tepat dalam memanfaatkan kesempatan untuk peningkatan penjualan, hingga keberadaan perusahaan di pasar bisa mengalami peningkatan atau dipertahankan (Petri, 2020).

\section{METODE PENELITIAN}

Riset ini memiliki tujuan untuk memberikan informasi terkait seberapa besar akibat dari pandemi Covid 19 terhadap keadaan ekonomi para pelaku UMKM di Provinsi Gorontalo, khususnya pada hutang usaha, omzet dan laba serta pemasaran UMKM di Provinsi Gorontalo. Riset ini menggunakan metode kuantitatif dalam pengumpulan data yaitu melalui kuesioner pada UMKM yang tersebar di wilayah Provinsi Gorontalo. Penyebaran kuesioner dilakukan menjelang akhir tahun 2020 yakni Oktober sampai Desember. Hasil kuesioner kemudian diolah dengan metode analisis statistik deskriptif, dimana metode ini digunakan untuk menganalisa data dengan mendeskripsi data yang dikumpulkan secara apa adanya tanpa bermaksud menarik kesimpulan dan mengeneralisirnya (Sugiyono, 2014).

Jumlah populasi UMKM di Provinsi Gorontalo tidak dapat diketahui secara pasti, sehingga untuk memudahkan peneliti menggunakan purposive sampling. Sample yang diolah pada penelitian ini didapatkan melalui teknik purposive sampling dengan kriteria inklusi, dalam hal ini adalah UMKM yang bergerak di bidang kuliner, handycraft, jasa, pertanian dengan skala usaha Rp500.000.000 juta ke bawah. Purposive sampling adalah teknik dalam menetapkan 


\section{Nominal: Barometer Riset Akuntansi dan Manajemen \\ P-ISSN: 2303-2065 E-ISSN: 2502-5430 \\ Volume 10 No 2 (2021)}

sample melalui cara memilah sample di antara populasi sesuai dengan yang dikehendaki oleh peneliti (tujuan dan permasalahan dalam penelitian), agar sample tersebut bisa mewakili karakteristik dalam populasi sebelumnya (Nursalam, 2015). Kriteria inklusi merupakan kriteria atau syarat-syarat yang harus dipenuhi untuk setiap populasi yang kemudian dapat diambil sebagai sample (Notoatmojo, 2010).

Data hasil kuisioner kemudian diolah menjadi informasi berbentuk grafik dan uraian.

\section{HASIL PENELITIAN DAN PEMBAHASAN}

Tigapuluh satu (31) pengusaha mikro, kecil dan menengah di Provinsi Gorontalo, mengaku terkena dampak pandemic covid 19 yang cukup signifikan selama tahun 2020. Dari 31 UMKM tersebut, 3 diantaranya memiliki skala usaha dengan rentang modal di bawah dari Rp500.000.000 dan selebihnya adalah usaha dengan skala di bawah dari Rp50.000.000. Dari data yang didapatkan, pandemic covid 19 ini mengakibatkan penurunan rata-rata omzet perminggu, problematika pemasaran produk yang mengakibatkan jumlah permintaan pasar menurun, perubahan jangkauan pemasaran pasar, hutang usaha yang bertambah, permasalahan pada produksi karena naiknya harga bahan baku serta permasalahan-permasalahan lainnya. Beberapa jenis usaha ini bergerak dibidang pertanian, jasa, fashion, furniture dan craft, serta selebihnya adalah kuliner.

\section{Bertambahnya Hutang Usaha}

Gambar 1 tampak mendeskripsikan kenaikkan atau bertambahnya hutang usaha yang terjadi selama masa pandemi covid 19 pada UMKM di Provinsi Gorontalo yang menjadi responden penelitian ini. Diantara 31 UMKM yang menjadi sample penelitian, terdapat 7 usaha yang tidak mengalami kenaikkan atau pertambahan hutang usaha, seperti K' Bakery, Alfcoff, Fazhandmade, Ikm Riyadh, Gkarawo, WLM Food, dan UKM Nurfarab. Selebihnya, menurut hasil pengumpulan data mengalami pertambahan hutang usaha cukup signifikan untuk membayar gaji karyawan, untuk melunasi pinjaman yang sudah jatuh tempo, serta untuk mengatasi kerugian-kerugian usaha yang diakibatkan oleh pandemi covid 19 . Beberapa usaha tersebut diantaranya adalah Moringa yang terpaksa melakukan pinjaman ke Bank sebesar Rp500.000.000 pada masa pandemi, padahal jauh sebelum masa pandemi sudah memiliki hutang usaha sebesar Rp250.000.000. Fay Grade Pinogu, yang bergerak di bidang usaha kuliner juga mengalami hal yang sama, terpaksa menambah hutang usahanya sebesar Rp210.000.000 di masa pandemi untuk 


\section{Nominal: Barometer Riset Akuntansi dan Manajemen \\ P-ISSN: 2303-2065 E-ISSN: 2502-5430 \\ Volume 10 No 2 (2021)}

menutupi kewajiban-kewajiban usahanya walaupun sebelumnya juga telah memiliki hutang usaha sebesar Rp200.000.000. Yang melonjak kenaikkan atau pertambahan hutang usahanya adalah Rahida Cookies, sebelumnya usaha ini hanya memiliki hutang usaha hanya sebesar Rp17.500.000, namun karena mengalami kesulitan di masa pandemi, Rahida Cookies terpaksa menambah pinjamannya jauh lebih besar dari sebelumnya sebesar Rp125.000.000.

\section{$\mathrm{Rp} 600,000,000$ \\ $\mathrm{Rp} 400,000,000$ \\ Rp200,000,000 \\ $\mathrm{Rp}$ -

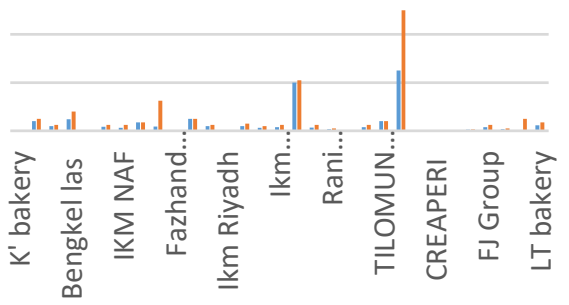 \\ - HUTANG USAHA SEBELUM COVID 19 \\ - HUTANG USAHA SELAMA COVID 19}

Gambar 1 Diagram Hutang Usaha UMKM

Di Provinsi Gorontalo Sebelum Dan Selama

Pandemi.

Bengkel Las yang bergerak di bidang jasa, memiliki kesulitan di masa pandemi covid 19 juga menambah hutang usahanya sebesar Rp80.000.000 untuk menutupi semua kerugian-kerugian usahanya serta melunasi kewajiban-kewajiban yang mendesak selama masa pandemi, meskipun awalnya bengkel ini juga sudah memiliki hutang usaha yang belum selesai juga sebesar Rp48.000.000. Sambal G, F
Cookies, dan VCO mengalami kenaikkan hutang usaha selama pandemi sebesar Rp50.000.000, bahkan VCO yang sebelumnya tidak memiliki hutang usaha terpaksa melakukan pinjaman untuk menutupi masa-masa sulitnya di masa pandemi covid 19. Demikian juga terjadi pada Pupuk Kita, D’Limututu, IKM Naf, Ummide, Sp Burger, White Swan, Idhan Cookies, Ikm Zaafirah, Ijah Cake's, Rani Cookies, Ankin Dc, Tilomungo, Creaperi, Home Molingo, FJ Group, UKM Bluedor, serta LT Bakery.

Hasil penelitian ini sejalan dengan penelitian Lim et al., (2020). Hasil penelitiannya menyatakan bahwa Pemerintah Kanada, memberikan fasilitas pinjaman darurat melalui pihak kreditur pada pengusaha-pengusaha UMKM sebagai langkah menutupi biaya-biya operasional UMKM dan mencegah dari kebangkrutan.

\section{Penurunan Rata-Rata Omzet dan}

\section{Laba Perminggu Sebelum dan Selama}

\section{Pandemi Covid 19}

Dampak pandemi covid 19 cukup dirasakan oleh para pelaku UMKM di Provinsi Gorontalo, baik dari berbagai jenis usaha kuliner, jasa, pengolahan produk pertanian, dan sebagainya. Jenis usahausaha tersebut, beberapa diantaranya merupakan sample penelitian ini. Para pelaku UMKM ini, tentunya paham betul betapa pandemi ini cukup berpengaruh 


\section{Nominal: Barometer Riset Akuntansi dan Manajemen}

P-ISSN: 2303-2065 E-ISSN: 2502-5430

Volume 10 No 2 (2021)

signifikan terhadap pendapatan atau omzet mereka. Bahayanya virus ini bukan hanya pada kesehatan manusia, tetapi juga sampai menyerang keadaan ekonomi masyarakat. Pembatasan sosial berskala besar yang diterapkan oleh pemerintah, juga mengakibatkan terbatasnya ruang gerak para pelaku atau pengusaha UMKM di Provinsi Gorontalo, hingga hal ini juga tentu saja mempengaruhi jumlah permintaan pasar yang ikut menurun. Permintaan pasar yang menurun ini mengakibatkan rata-rata omzet 31 sample UMKM di Provinsi Gorontalo ini menurun hingga lebih dari $50 \%$ selama masa pandemi covid 19. Hasil penelitian ini sejalan dengan hasil penelitian yang dilakukan oleh Azimah et al., (2020) yang menyatakan bahwa telah terjadi penurunan omzet dan laba pada pedagang-pedang yang ada di pasar Kalikotes, pasar Klepu, dan pasar Wonogiri.

Gambar 2 menjelaskan dampak dan pengaruh pandemi Covid 19 pada penurunan omzet atau pendapatan pelaku UMKM di Provinsi Gorontalo yang menjadi sample dalam penelitian ini. Terdapat 31 sample pengusaha yang masih tetap menjalankan bisnisnya selama masa pandemi. Berdasarkan gambar diagram 1.1, K'Bakery yang memperoleh rata-rata omzet perminggu sebelum pandemi sebesar Rp10.000.000 sementara berjualan di masa pandemi hanya memperoleh omzet rata-rata perminggu sebesar Rp4.000.000. Selain mengalami penurunan permintaan produk, pemilik usaha K'Bakery juga mengeluhkan kesulitan di masa pandemi, khususnya pada harga bahan baku yang mengalami kenaikkan sehingga proses produksi terganggu. Hal ini juga dirasakan oleh pengusaha Sambal G yang memperoleh rata-rata omzet perminggu sebelum pandemi sebesar Rp15.000.000 sementara berjualan di masa pandemi mengalami penurunan tajam hingga omzet rata-rata perminggu hanya sebesar Rp5.000.000. Pupuk Kita, yang memperoleh rata-rata omzet perminggu sebelum pandemi sebesar Rp3.000.000 sementara berjualan di masa pandemi hanya memperoleh omzet rata-rata perminggu sebesar Rp1.000.000.

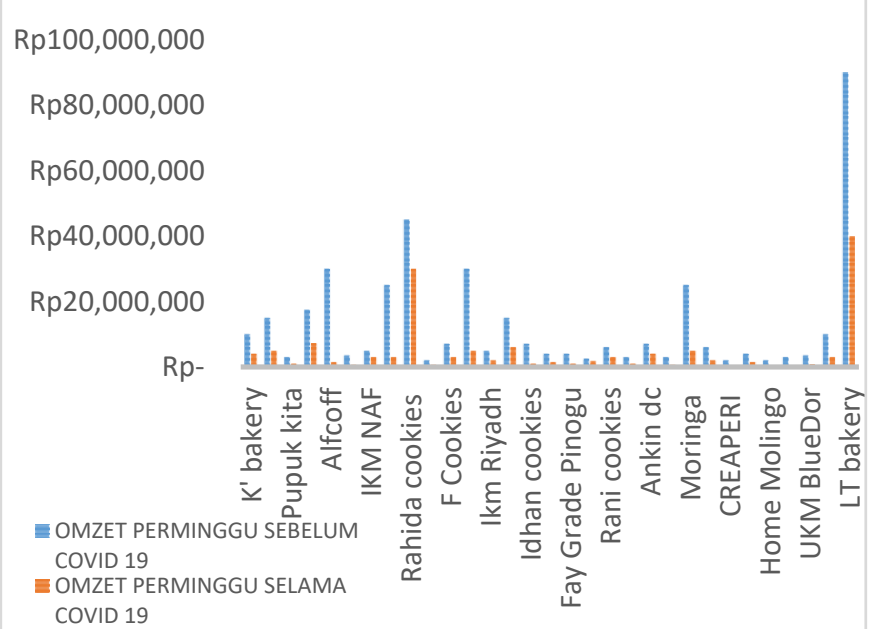

Gambar 2: Diagram Pendapatan Perminggu UMKM Di Provinsi Gorontalo Sebelum Dan Selama Pandemi.

Bengkel Las, yang memperoleh ratarata omzet perminggu sebelum pandemi sebesar Rp17.500.000 sementara beroperasi 
di masa pandemi hanya memperoleh omzet rata-rata perminggu sebesar Rp7.300.000. Alfcoff, yang memperoleh rata-rata omzet perminggu sebelum pandemi sebesar Rp30.000.000 sementara berjualan di masa pandemi hanya memperoleh omzet rata-rata perminggu sebesar Rp1.500.000. D'Limututu, yang memperoleh rata-rata omzet perminggu sebelum pandemi sebesar Rp3.500.000 sementara berjualan di masa pandemi hanya memperoleh omzet rata-rata perminggu sebesar Rp500.000. IKM NAF, yang memperoleh rata-rata omzet perminggu sebelum pandemi sebesar Rp5.000.000 sementara berjualan di masa pandemi hanya memperoleh omzet rata-rata perminggu sebesar Rp3.000.000. Ummide, yang memperoleh rata-rata omzet perminggu sebelum pandemi sebesar Rp25.000.000 sementara berjualan di masa pandemi hanya memperoleh omzet rata-rata perminggu sebesar Rp3.000.000. Rahida Cookies, yang memperoleh rata-rata omzet perminggu sebelum pandemi sebesar Rp45.000.000 sementara berjualan di masa pandemi hanya memperoleh omzet rata-rata perminggu sebesar Rp30.000.000. Fazhandmade, yang memperoleh rata-rata omzet perminggu sebelum pandemi sebesar Rp2.000.000 sementara berjualan di masa pandemi hanya memperoleh omzet rata-rata perminggu sebesar Rp500.000.
F Cookies, yang memperoleh ratarata omzet perminggu sebelum pandemi sebesar Rp7.000.000 sementara berjualan di masa pandemi hanya memperoleh omzet rata-rata perminggu sebesar Rp3.000.000. Sp Burger, yang memperoleh rata-rata omzet perminggu sebelum pandemi sebesar Rp30.000.000 sementara berjualan di masa pandemi hanya memperoleh omzet rata-rata perminggu sebesar Rp5.000.000. Ikm Riyadh, yang memperoleh rata-rata omzet perminggu sebelum pandemi sebesar Rp5.000.000 sementara berjualan di masa pandemi hanya memperoleh omzet rata-rata perminggu sebesar Rp2.000.000. White Swan, yang memperoleh rata-rata omzet perminggu sebelum pandemi sebesar Rp15.000.000 sementara berjualan di masa pandemi hanya memperoleh omzet rata-rata perminggu sebesar Rp6.000.000. Idhan cookies, yang memperoleh rata-rata omzet perminggu sebelum pandemi sebesar Rp7.000.000 sementara berjualan di masa pandemi hanya memperoleh omzet rata-rata perminggu sebesar Rp1.000.000. Ikm Zaafirah, yang memperoleh rata-rata omzet perminggu sebelum pandemi sebesar Rp4.000.000 sementara berjualan di masa pandemi hanya memperoleh omzet rata-rata perminggu sebesar Rp1.500.000. Fay Grade Pinogu, yang memperoleh rata-rata omzet perminggu sebelum pandemi sebesar Rp4.000.000 sementara berjualan di masa 


\section{Nominal: Barometer Riset Akuntansi dan Manajemen \\ P-ISSN: 2303-2065 E-ISSN: 2502-5430 \\ Volume 10 No 2 (2021)}

pandemi hanya memperoleh omzet rata-rata perminggu sebesar Rp1.000.000.

Ijah Cake's, yang memperoleh ratarata omzet perminggu sebelum pandemi sebesar Rp2.500.000 sementara berjualan di masa pandemi hanya memperoleh omzet rata-rata perminggu sebesar Rp1.800.000. Rani cookies, yang memperoleh rata-rata omzet perminggu sebelum pandemi sebesar Rp6.000.000 sementara berjualan di masa pandemi hanya memperoleh omzet rata-rata perminggu sebesar Rp3.000.000. Gkarawo, yang memperoleh rata-rata omzet perminggu sebelum pandemi sebesar Rp3.000.000 sementara berjualan di masa pandemi hanya memperoleh omzet rata-rata perminggu sebesar Rp1.000.000. Ankin dc, yang memperoleh rata-rata omzet perminggu sebelum pandemi sebesar Rp7.000.000 sementara berjualan di masa pandemi hanya memperoleh omzet rata-rata perminggu sebesar Rp4.000.000. Tilomunggo, yang memperoleh rata-rata omzet perminggu sebelum pandemi sebesar Rp3.000.000 sementara berjualan di masa pandemi hanya memperoleh omzet rata-rata perminggu sebesar Rp500.000. Moringa, yang memperoleh rata-rata omzet perminggu sebelum pandemi sebesar Rp25.000.000 sementara berjualan di masa pandemi hanya memperoleh omzet rata-rata perminggu sebesar Rp5.000.000. WLM Food, yang memperoleh rata-rata omzet perminggu sebelum pandemi sebesar Rp6.000.000 sementara berjualan di masa pandemi hanya memperoleh omzet rata-rata perminggu sebesar Rp2.000.000.

Creaperi, yang memperoleh rata-rata omzet perminggu sebelum pandemi sebesar Rp2.000.000 sementara berjualan di masa pandemi sama sekali tidak memperoleh pendapatan hingga pengusaha memutuskan untuk tidak berjualan. UKM Nurfarab, yang memperoleh rata-rata omzet perminggu sebelum pandemi sebesar Rp4.000.000 sementara berjualan di masa pandemi hanya memperoleh omzet rata-rata perminggu sebesar Rp1.500.000. Home Molingo, yang memperoleh rata-rata omzet perminggu sebelum pandemi sebesar Rp2.000.000 sementara berjualan di masa pandemi hanya memperoleh omzet rata-rata perminggu sebesar Rp400.000. FJ Group, yang memperoleh rata-rata omzet perminggu sebelum pandemi sebesar Rp3.000.000 sementara berjualan di masa pandemi hanya memperoleh omzet rata-rata perminggu sebesar Rp100.000. UKM BlueDor, yang memperoleh rata-rata omzet perminggu sebelum pandemi sebesar Rp3.500.000 sementara berjualan di masa pandemi hanya memperoleh omzet_rata-rata perminggu sebesar Rp750.000. VCO, yang memperoleh rata-rata omzet perminggu sebelum pandemi sebesar Rp10.000.000 sementara berjualan di masa pandemi hanya 


\section{Nominal: Barometer Riset Akuntansi dan Manajemen \\ P-ISSN: 2303-2065 E-ISSN: 2502-5430 \\ Volume 10 No 2 (2021)}

memperoleh omzet rata-rata perminggu sebesar Rp3.000.000. LT bakery, yang memperoleh rata-rata omzet perminggu sebelum pandemi sebesar Rp90.000.000 sementara berjualan di masa pandemi hanya memperoleh omzet rata-rata perminggu sebesar Rp40.000.000.

Beberapa responden atau pelaku usaha menyiasati penurunan omzet ini, dengan mengurangi produksi, dan melakukan penghematan untuk going concern atau keberlanjutan usaha kedepannya. Bahkan penurunan omzet besar-besaran ini mengakibatkan salah satu responden terpaksa untuk menghentikan sementara proses produksinya.

\section{Perubahan Jangkauan Pemasaran} Sebelum dan Selama Pandemi Covid 19

Gambar 3 merupakan hasil olahan data yang mendeskripsikan dampak pandemi Covid 19 pada perubahan jangkauan pemasaran sebelum dan selama pandemi yang dialami oleh pengusaha UMKM di Provinsi Gorontalo yang menjadi sample dalam penelitian ini.

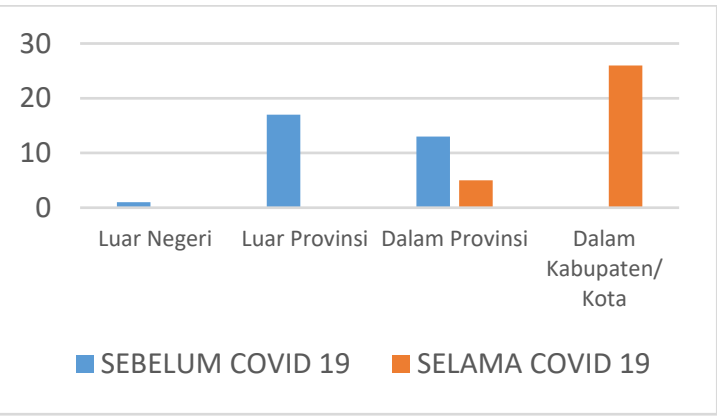

Gambar 3: Diagram Jangkauan Pemasaran UMKM Di Provinsi Gorontalo Sebelum Dan Selama Pandemi.

Hasil penelitian ini sejalan dengan penelitian yang dilakukan Amri (2020), bahwa dampak terhadap bisnis makanan dan minuman serta pariwisata yang paling signifikan mengalami penurunan pemasaran.

Sebelum pandemi covid 19 mewabah di Provinsi Gorontalo, dengan kasus pertama kali terkonfirmasi pada awal April 2020, ada salah satu responden yang memiliki jangkauan pemasarannya sampai Luar Negeri, terutama Ikm Riyadh yang bergerak di bidang kuliner. Ikm Riyadh memproduksi sambal sagela, sambal tuna, abon tuna dan mengekspornya ke luar Negeri. Namun setelah virus covid ini mewabah di Provinsi Gorontalo, pemasaran produk-produk yang dihasilkan Ikm Riyadh hanya dapat menjangkau wilayah Kabupaten atau Kota Gorontalo saja. Hal ini tidak berbeda jauh dengan UMKM lainnya seperti K' Bakery, Sambal G, Pupuk Kita, Alfcoff, IKM Naf, Ummide, F Cookies, Idhan Cookies, Ikm Zaafirah, Ijah Cake's, Rani Cookies, serta FJ 


\section{Nominal: Barometer Riset Akuntansi dan Manajemen \\ P-ISSN: 2303-2065 E-ISSN: 2502-5430 \\ Volume 10 No 2 (2021)}

Group, pemasaran produk-produk yang dihasilkan UMKM ini menjangkau sampai di luar Provinsi Gorontalo sebelum pandemi Covid 19, lalu hanya mampu memasarkan ke lingkungan dalam kabupaten/ kota selama masa pandemi. Rahida Cookies, Fay Grade Pinogu, Gkarawo, Tilomungo, Moringa, sebelum masa pandemi covid 19 memiliki jangkauan pasar sampai luar Provinsi Gorontalo, namun setelah masa pandemi hanya mampu memasarkan produknya di dalam Provinsi Gorontalo. Pengusaha lainnya di Bengkel Las, D'Limutu, Fazhandmade, Sp Burger, White Swan, Ankin Dc, WLM Food, Creaperi, UKM Nurfarab, Home Molingo, UKM Bluedor, VCO, LT Bakery yang memiliki jangkauan untuk memasarkan produk di dalam Provinsi Gorontalo, pandemi covid 19 mengakibatkan UMKM ini hanya mampu memasarkan produknya di dalam kabupaten atau kota Gorontalo saja.

Beberapa pelaku usaha mengeluhkan dengan adanya covid 19 ini, daya beli masyarakat berkurang terlebih dengan adanya kebijakan pemerintah untuk diam di rumah atau stay at home, serta PSBB (Pembatasan Sosial Berskala Besar) dan menutup akses untuk wisatawan yang berkunjung ke Provinsi Gorontalo, sehingga para pembeli dari luar daerah menurun, bahkan beberapa order dari jama'ah haji maupun umroh terpaksa dibatalkan.
Pemilik-pemilik usaha ini berharap kepada pemerintah untuk memperhatikan UMKM ini yang pendapatannya hanya bergantung pada jumlah orang atau wisatawan yang berkunjung. Pengusaha di bidang pertanian juga mengeluhkan bahwa pembayaran pupuk oleh para petani dilakukan biasanya dengan cash tunda, petani-petani ini membayar pupuknya setelah panen, sementara hasil panen para petani ini masih belum mendapatkan pembeli, akibatnya petani belum dapat membayar pupuk.

\section{SIMPULAN DAN SARAN}

Berdasarkan sampel penelitian yang diambil dari 30 lebih UMKM yang terdampak covid 19 di Provinsi Gorontalo, dapat disimpulkan bahwa pandemic covid 19 ini sangat berpengaruh terhadap pertumbuhan ekonomi UMKM di Provinsi Gorontalo terutama pada aspek hutang usaha yang meningkat selama masa pandemic, aspek perolehan omzet yang berdampak pada penurunan laba usaha serta dari aspek jangkauan pemasaran yang juga ikut menurun. Para pelaku UMKM mengharapkan adanya kebijakan pemerintah yang dapat menstimulus keadaan ekonomi UMKM serta keputusankeputusan yang diambil oleh pemerintah dapat mendukung pertumbuhan dan keberlanjutan UMKM ini untuk bertahan dan keluar dari krisis pandemic. 
Keterbatasan penelitian ini ada pada objek penelitian yakni UMKM yang bergerak di bidang kuliner, handycraft, jasa, pertanian dengan skala usaha Rp500.000.000 juta ke bawah. Atas temuan dan keterbatasan penelitian ini, diharapkan untuk penelitian selanjutnya dapat memperluas lingkup penelitian dengan sampel penelitian pada UMKM yang bergerak pada jenis usaha lainnya misalnya dagang dan lain sebagainya.

\section{DAFTAR PUSTAKA}

Amri, A. (2020). Dampak Covid-19 Terhadap UMKM di Indonesia. Jurnal Brand, 2(1), 123-130. https://www.academia.edu/42672824 /Dampak_Covid-

19_Terhadap_UMKM_di_Indonesia

Apriliana, F. (2012). Kemampuan Laba Bersih, Arus Kas Aktivitas Operasi Historis Dan Komponen-Komponen Akrual Dalammemprediksi Arus Kas Aktivitas Operasi Dimasa Mendatang. Semarang, Universitas Diponogoro, 2015.

Atkeson, A. (2020). What will be the economic impact of COVID-19 in the US? Rough estimates of disease scenarios. National Bureau of Economic Research. https://doi.org/https://doi.org/10.3386 /w26867

Avanesyan, V. (2020). Assessment of the economic impact of restrictive government policies (lockdowns) to combat coronavirus [RussianArmenian University]. http://inecbus.rau.am/rus/11/1226

Azimah, R. N., Khasanah, I. N., Pratama,
R., Azizah, Z., Febriantoro, W., \& PURNOMO, S. R. S. (2020). Analisis Dampak Covid-19 Terhadap Sosial Ekonomi Pedagang Di Pasar Klaten Dan Wonogiri. EMPATI: Jurnal Ilmu Kesejahteraan Sosial, 9(1), 59-68. https://doi.org/10.15408/empati.v9i1. 16485

Baldwin, R., \& Weder di Mauro, B. (2020). Economics in the time of COVID-19. CEPR Press. https://voxeu.org/content/economicstime-covid-19

Beglaryan, M., \& Shakhmuradyan, G. (2020). The impact of COVID-19 on small and medium-sized enterprises in Armenia: Evidence from a labor force survey. Small Business International Review, 4(2), e298. https://doi.org/10.26784/sbir.v4i2.29 8

Chaniago, A. A. (1998). Ekonomi 2. Angkasa.

Cowling M, Liu W, Ledger A, et al. (2015). What really happens to small and medium-sized enterprises in a global economic recession? UK evidence on sales and job dynamics. International Small Business Journal, $33(5)$, 488-513. https://doi.org/https://doi.org/10.1177 /0266242613512513

Danang Sunyoto. (2012). Dasar-Dasar Manajemen Pemasaran. CAPS.

Fernandes, N. (2020). Economic effects of coronavirus outbreak (COVID-19) on the world economy. SSRN Electronic Journal. https://doi.org/https://doi.org/10.2139 /ssrn.3557504

Gourinchas, P. O. (2020). Flatten the curve of infection and the curve of recession at the same time. Foreign Affairs. https://www.foreignaffairs.com/articl es/world/2020-03-26/flatten-curve- 
infectionand-curve-recession-sametime

Ismail, J. (2020). Eksistensi UMKM Diterpa Badai Covid 19: Pertahanan Asset dalam Cash Is King, Relationship Marketing, Technology Skill dan Sprituality Improvements. In T. Marlin Arika (Ed.), Telisik Seputar Covid-19: Percikan Pemikiran Dosen Muda IAIN Sultan Amai Gorontalo (Covid 19, pp. 97112). INSAN CENDEKIA MANDIRI.

Janita, I. (2012). Analisis kemampuan laba kotor, laba bersih dan arus kas operasi dalam memprediksi arus kas di masa mendatang. Universitas Lampung.

Lim, D. S. K., Morse, E. A., \& Yu, N. (2020). The impact of the global crisis on the growth of SMEs: A resource system perspective. International Small Business Journal: Researching Entrepreneurship, 38(6), 492-503. https://doi.org/10.1177/02662426209 50159

McKibbin, W. J., \& Fernando, R. (2020). The global macroeconomic impacts of COVID-19: Seven scenarios. SSRN Electronic Journal. https://doi.org/https://doi.org/10.2139 /ssrn.3547729

Notoatmojo, S. (2010). Metodologi Penelitian Kesehatan. Rineka Cipta.

Nursalam. (2015). Metodologi ilmu keperawatan (4th ed.). Salemba Medika.

Petri, Mia Muliyani. (2020). Strategi Pemasaran Dalam Mempertahankan Bisnis Umkm Di Tengah Pandemi Covid-19. Journal of Chemical Information and Modeling, 53(9),
1689-1699.

Philip Kotler, G. A. (2004). Dasar-Dasar Pemasaran". (Alexander Sindoro (ed.); 9 Jilid 1). PT Indeks.

Renner, C. (2020). Index of consumer confidence (April 2020). The Conference Board of Canada. Www.Conferenceboard.ca/eLibrary/Research/Icc/2020/10690.

Richards, C. (2008). Crisis Management : Operating Inside Their OODA Loops. First Adaptive Leadership Symposium.

https://scholar.google.com/scholar?cl uster $=4079931246382157302 \& \mathrm{hl}=\mathrm{en}$ \&as_sdt $=2005 \&$ sciodt $=0,5 \&$ scioq $=R$ ichards+Chet +2008

Rosita, R. (2020). Pengaruh Pandemi Covid-19 Terhadap Umkm Di Indonesia. Jurnal Lentera Bisnis, 9(2), https://doi.org/10.34127/jrlab.v9i2.38 0

Senderovitz M, K. K. and S. P. (2016). Four years on: Are the gazelles still running? A longitudinal study of firm performance after a period of rapid growth. International Small Business Journal, 34(4), 391-411. https://doi.org/https://doi.org/10.1177 /0266242614567483

Sugiyono. (2014). Metode Penelitian Pendidikan Pendekatan Kuantitatif, Kualitatif, dan $R \& D$. Alfabeta.

Swastha, B. (1993). Manajemen Pemasaran Modern. Liberty.

The Statement of Financial Accounting Concept (SFAC) No.6. 1978. Financial Accounting Standards Board (FSAB). 